\title{
SWOT Analysis for Tourism Development Strategy of Samosir Regency
}

\author{
Toman Sony Tambunan a 1 \\ a Sekolah Tinggi Ilmu Ekonomi LMII, Medan, Indonesia
}

\begin{abstract}
APA Citation:
Tambunan, T.S. (2020). SWOT analysis for tourism development strategy of Samosir. TIJAB (The International Journal of Applied Business), 4(2), 90-105.

Submission Date: $27 / 07 / 2020$

Acceptance Date: 09/11/2020
\end{abstract}

\begin{abstract}
Samosir Regency is an area that has the potential to be developed as a tourism destination through the utilization of various potential natural beauty, local wisdom, and the historical value of cultural civilization, so as to increase regional income, improve the community's economy, grow the business sector, introduce local cultural values, and contribute in developing the world of education. This study aims to analyze the strengths, weaknesses, opportunities and threats in the development of tourism in Samosir Regency as a tourist attraction. Data were collected through observation, interviews and literature study. Data analysis uses descriptive qualitative analysis. The results of the data will be used to determine the strengths, weaknesses, opportunities and threats of tourism objects in Samosir Regency. The conclusion of this study states that for the tourism development strategy of Samosir Regency, they are (1) improving the quality of facilities and infrastructure that supports tourism, (2) increasing tourism activities on a national and international scale, (3) promoting attractions on an ongoing basis to the national and international level, (4) developing various values of tourist attraction products, (5) involving the participation of the community and all interested parties in the management of attractions, and (6) improving the competency of human resources for tourism actors.
\end{abstract}

Keywords: swot analysis, tourism development, Samosir regency

This is an open access article under the CC BY-NC-SA license.

\section{Introduction}

Tourism is an important factor for the progress of a country or region. The tourism sector is believed to contribute to the increase in Regional Original Revenues for regions that have good natural resource potential to be managed, and in general contribute to improving the economy of a country. Manzoor (2019) explained in his research that there was a positive and significant effect of tourism on economic growth for a country, as well as for the employment sector. Richardson (2014) stated that tourism development is increasingly viewed as an important tool in promoting economic growth, alleviating

\footnotetext{
${ }^{1}$ Corresponding author.

E-mail address: toms_tambunan@yahoo.co.id
} 
poverty, and advancing food security. Obalade and Dubey (2014) stated that tourism is an important factor in development and growth in all countries, creating a positive impact on the economic and social situation of a country.

Based on the Law of the Republic of Indonesia Number 28 of 2009, regional income is all regional rights that are recognized as an addition to the net worth in the relevant fiscal year period. Regional income is broken down according to regional government affairs, organizations, groups, types, objects and details of revenue objects. Regional revenues are grouped into: Regional Original Revenues, Balancing Funds, Others Legitimate Regional Revenues. Regional Original Revenue is revenue obtained by the Region which is collected based on regional regulations in accordance with statutory regulations. Local Own Revenue aims to give authority to the Regional Government to fund the implementation of regional autonomy in accordance with the Regional potential as a manifestation of Decentralization.

Tourism also has a positive impact on regional economic growth, increasing people's income, increasing business opportunities, increasing the value of ownership of assets (such as land values), able to create jobs for the community. Based on the 2020 Regional Government Financial Report of Samosir Regency, regional revenue related to tourism activities, including the receipt of Retribution for Lodging/guesthouses/villas in 2019 is IDR 47,305,000.00; Retribution for Recreational and Sports Places in 2019 is IDR 1,250,428,000.00; Retribution for Sales of Regional Business Production in 2019 is IDR $173,970,000.00$.

To measure the level of economic growth of a region, it can be seen from the Gross Regional Domestic Product. Based on the 2020 Regional Government Financial Report of Samosir Regency, it is stated that the Gross Regional Domestic Product is the gross added value of all goods and services created or produced in the domestic area of a country arising from various economic activities in a certain period regardless of whether the production factors are owned by resident or non-resident. The compilation of Gross Regional Domestic Product can be done through 3 (three) approaches, namely the production, expenditure and income approach which are presented on the basis of current prices and constant (real) prices. Gross Regional Domestic Product based on current prices or known as nominal Gross Regional Domestic Product is compiled based on the prevailing prices in the calculation period, and aims to see the structure of the economy. Meanwhile, Gross Regional Domestic Product based on constant (real) prices is arranged based on prices in the base year and aims to measure economic growth. The Gross Regional Domestic Product of Samosir Regency which is calculated based on the Applicable Price according to the business field of Samosir Regency continues to increase. This can be seen in the data for 2018 is IDR 4,085,203 million, in 2019 is IDR 4,434,721.24 million. The Gross Regional Domestic Product of Samosir Regency which is calculated based on the basis of constant prices continues to increase. This can be seen in the data for 2018 is IDR 2,931,698 million, and in 2019 is IDR 3,098,740.91 million.

The increase in income per capita in Samosir Regency shows an increase in the welfare of the Samosir people. The increase in per capita income of the people of Samosir Regency can be triggered by high economic growth and a controlled inflation rate. The income per capita of Samosir Regency in 2019 reached a value of IDR 35.14 million, an increase of 8.22 percent when compared to 2018. In 2019, the agricultural sector absorbed the largest number of workers, reaching $59.70 \%$, and the tourism sector absorbed the most workforce, reaching 21.50\%. (Regional Government Financial Report in 2019).

The development of the tourism sector in an area, will also move other sectors to develop as a cycle of mutual support, including agriculture, plantation, livestock, fisheries and marine sectors. In addition, through tourism will increase public awareness of the surrounding natural environment, increase the 
love of the community to preserve cultural values, provide opportunities for people to introduce their arts and culture, improve social welfare for the community, and increase public knowledge of the values of life. Ardahaey (2011) states that tourism is recognized as supporting the goals of economic development in every country; add value to foreign exchange; supporting exports and imports for the industrial sector; supporting the protection of natural resources; support the goal of developing social, cultural and historical values. Meyer and Meyer (2015) state that the tourism sector as a labor-intensive industry has many benefits for local areas including poverty alleviation and local economic development. Zaei and Zaei (2013) state that tourism is a sector that can contribute to the economic growth of a region; generate social benefits for the area (ie small and medium enterprise development, new job creation, infrastructure improvements); and contribute to the preservation of the natural environment. Gnanapala and Sandaruwani (2016) state that the tourism sector can provide many benefits for economic and socio-cultural development for an area. Aref (2011) states that tourism has a positive effect on people's quality of life, emotional well-being, community welfare, and people's income.

Samosir Regency is a regency located in the administrative region of North Sumatra Province, which has the slogan "Negeri Indah Kepingan Surga". Samosir Regency has the potential and good natural resources to be developed as a nature tourism area, cultural tourism, spiritual tourism, and as a center for educational development. The potential of natural wealth possessed by Samosir Regency has become an attraction for tourists from local, domestic and foreign regions who want to visit. Samosir Regency has an area of $\pm 2,069.05 \mathrm{~km} 2$, and is surrounded by Lake Toba. During the year, several areas in Samosir Regency have a climate of high rainfall. Based on data from Tourism Services of Samosir Regency, the visiting number of tourists to Samosir Regency in the year 2019 increased by 10,46 percent that was from 378.649 visits in 2018 to 418,271 visits in 2019 that consisted of 367.301 visits of domestic tourists $(87,81$ percent) and 50.970 visits of foreign tourists (12,19 percent). Furthermore, to find out the potential resources owned by Samosir Regency, it will be discussed in the discussion section, and to find out the types of tourism destinations in Samosir Regency, it can be seen in Table-1.

The research questions of this study are:

1. What potential does Samosir Regency have as an attraction for nature tourism, cultural tourism and spiritual tourism?

2. What is the strategy for developing tourism in Samosir Regency as a "Tourism City"?

The purpose of this research is to contribute ideas for all parties regarding the tourism development strategy of Samosir Regency as a "Tourism City". Also, it aims to determine the potential of Samosir Regency as an attraction for nature tourism, cultural tourism and spiritual tourism, and to establish a strategy for the development of tourism in Samosir Regency.

\section{Literature Review}

Based on "Law of the Republic of Indonesia Number 10 of 2009", what is meant by Tourism is a variety of tourism activities and is supported by various facilities and services provided by the community, business people, the Government, and the Regional Government. Tourism is an overall activity related to tourism and is multidimensional and multidisciplinary in nature which emerges as a manifestation of the needs of each person and country as well as interactions between tourists and the local community, fellow tourists, the Government, Regional Government and entrepreneurs. Tourism aims to: First, Promote economic growth. Second, improve people's welfare. Third, eliminate poverty. Fourth, Overcoming unemployment. Fifth, Preserve nature, environment and resources. Sixth, Promote culture. Seventh, Raising the image of the nation. Eighth, Cultivating the taste of the country's homeland. Ninth, Strengthening national identity and unity. Tenth, Strengthening friendship between nations. 
Feili, et al., (2017) stated that one of the focus areas in the sustainable development goals is tourism. Because, tourism is a major source of income for many countries, and affects the economy for a country. Tourism is a source of income and can be an important tool for economic and social development in society. Vladi (2014) wrote that to build a tourism brand for a country is to build a competitive advantage. Satya, et al., (2018) stated that the development of a tourism strategy must be linked with other industries to form a unity that needs each other. The role of the Central and Local Governments as regulators and providers of tourism infrastructure is very important in driving the tourism sector.

Goranczewski and Puciato (2010) define tourism destination management as a process of achieving goals, using human, material, natural and information resources, and involving activities related to planning, organization, motivation and control. Furthermore, it is stated that strategic management of tourism destinations emphasizes the following: First, pay attention to the strategic objectives (fundamental and main) of a tourism destination. Second, it shows a time horizon that lasts a long time. Third, it is connected with the creation of a rational strategic plan. Fourth, involves adjusting a tourism destination to its unstable environment. Fifth, the various social groups and stakeholders involved must participate in the development and implementation of the plan. Sixth, bringing about structural changes in tourism destinations. Seventh, connected with the need to make choices in conditions of uncertainty and risk.

Hitt, et al. (1997) assert that strategy is a number of integrated and coordinated actions that are set for the management of core competencies, as well as for creating competitiveness. What is meant by core competencies are resources and capabilities that have been determined as a source of competitive advantage for the company against its competitors.

Finding and analyzing the resources and core competencies of an organization are conducted through the concept of Strength, Weaknesses, Opportunities and Threats (SWOT) analysis, which provides an understanding that an organization must adapt its various internal activities to external realities in order to achieve the objectives is expected. Opportunities will provide opportunities for an organization, if the organization manages its resources to seize opportunities. The concept component of Strength, Weaknesses, Opportunities and Threats (SWOT) analysis is:

a. Strength is the utilization and management of an organization's potential or resources effectively in order to achieve its objectives.

b. Weaknesses is the limitations or inability of the resources of the organization so that it can hinder the achievement of goals.

c. Opportunities is a situation in the general environment that can support an organization to achieve strategic competitiveness.

d. Threats is a situation in the general environment that can disrupt (not support) the activities of an organization in achieving its strategic competitiveness. Hitt, et al. (1997).

Strength Opprotunities Strategy (SO-Strategy), use the organization's internal strength to take advantage of external opportunities. Hunger and Wheelen (2003), mention that SO Strategy by thinking of certain ways by an organization can use its strengths to take advantage of the opportunities that exist.

Weaknesses-Opportunities Strategy (WO-Strategy) aims to increase internal weaknesses by taking advantage of external opportunities. Hunger and Wheelen (2003), stated that the WO strategy is a strategy to benefit from the opportunities that exist by overcoming various weaknesses of various resources owned.

The Strength-Threats Strategy (ST-Strategy) is a strategy of gaining from the strength of the available resources to avoid or reduce threats from the external environment. Hunger and Wheelen (2003) stated that ST strategy is a defensive strategy to overcome weaknesses and avoid threats. 
Weakness-Threats Strategy (WT-Strategy) is a defensive strategy to reduce internal weaknesses and avoid external threats.

\section{Method}

\subsection{Methods}

The method used in writing this research is the Literature Study method, namely through the collection of material, data and information from various literatures such as books, journals, and articles relating to the issues discussed. The discussion is carried out in a descriptive analysis to explain various matters related to the research title.

\subsection{Data collection procedures}

Data analysis method used in this study is a qualitative research method, a research method based on the philosophy of post-positivism used to examine natural conditions of objects, where researchers are as key instruments. Data collection techniques are carried out in a combined manner. Data analysis is qualitative and the results put more emphasis on a meaning. (Sugiyono, 2010).

\subsection{Data analysis}

The stages of data analysis include the Codification of the data, which is the stage where researchers do the naming of research results, so that the classification of themes can be obtained from the results of the study. Second, the presentation of data is the stage in which researchers use matrices and diagrams to present research findings, so that categories or groupings can be made. Third, drawing conclusions or verification is the stage where researchers interpret the findings in the research process, so that a conclusion can be drawn from the findings of the data (Afrizal, 2016).

\section{4. $\quad$ Results}

Samosir is a regency located in North Sumatra Province consisting of 9 (Nine) Subdistricts, which are Subdistricts Pangururan, Ronggur Nihuta, Sianjur Mula-Mula, Simanindo, Nainggolan, Onan Runggu, Palipi, Harian, dan Sitio-tio. Geographically, Samosir Regency is located between 2021 '38 " 2049 ' 48 " North Latitude and 98024 ' 00 " - 99001 ' 48 " East Longitude with an elevation between 9042.157 meters above sea level. The area is $\pm 2.069,05 \mathrm{Km} 2$, consists of land area $\pm 1.444,25 \mathrm{Km} 2(69,80$ percent) is the entire Samosir Island which is surrounded by Lake Toba and part of the mainland area of Sumatra Island, and the area of the lake $\pm 624,80 \mathrm{Km} 2$ (30,20 percent). Samosir Regency is bordered by several regencies, including North Side, which is bordered by Karo Regency and Simalungun Regency; South side, which is bordered by North Tapanuli Regency and Humbang Hasundutan Regency; West side, which is bordered by Dairi Regency and West Pakpak Regency; East side is bordered by Toba Regency. Based on administrative areas, Samosir Regency consists of 6 Urban, 128 Rural, 360 Dusun (village), dan 20 Lingkungan (village).

Based on the results of observations and literature studies for tourist destinations in Samosir regency, it is detailed in Table 1 below. 
Table 1. Tourist destinations in samosir regency

\begin{tabular}{|c|c|c|c|}
\hline No. & Name of tourism object & Subdistrict & Type of tourism object \\
\hline 1. & Makam Tua Raja Sidabutar & Simanindo & History and Culture \\
\hline 2. & Batu Kursi Persidangan Siallagan & Simanindo & Culture \\
\hline 3. & Museum Huta Bolon & Simanindo & History and Culture \\
\hline 4. & Museum Tomok & Simanindo & History and Culture \\
\hline 5. & Museum Gok Asi Simanindo & Simanindo & History and Culture \\
\hline 6. & Kawasan Agro Wisata Aek Natonang & Simanindo & Natural \\
\hline 7. & Pertunjukan Sigale-gale & Simanindo & Culture \\
\hline 8. & Kawasan Tuktuk Siadong & Simanindo & Natural \\
\hline 9. & Kawasan Wisata Siulakhosa Bukit Beta & Simanindo & Natural \\
\hline 10. & Tuktuk Asu & Simanindo & Natural \\
\hline 11. & Pulo Malau & Simanindo & Natural \\
\hline 12. & Batu Kursi Parhapuran di Ambarita & Simanindo & History \\
\hline 13. & Gua Lontung & Simanindo & Natural \\
\hline 14. & Sipokki & Simanindo & History and Culture \\
\hline 15. & Gua ALam Sangkal & Simanindo & Natural \\
\hline 16. & Pantai Sibolazi & Simanindo & Natural \\
\hline 17. & Batu Marhosa & Simanindo & History and Culture \\
\hline 18. & Situs Pagar Batu & Simanindo & History and Culture \\
\hline 19. & Pantai Batu Hoda & Simanindo & Natural \\
\hline 20. & Kuburan di Atas Pohon & Simanindo & History \\
\hline 21. & Pea Roba & Simanindo & Natural \\
\hline 22. & Pantai Langit & Simanindo & Natural \\
\hline 23. & Pantai Tandarabun & Simanindo & Natural \\
\hline 24. & Bulu Turak & Simanindo & History \\
\hline 25. & PantaiPasir PutihParbaba & Pangururan & Natural \\
\hline 26. & Pemandaian Air Panas & Pangururan & Natural \\
\hline 27. & Museum Gereja Katholik Inkulturatif & Pangururan & Culture \\
\hline 28. & Kawasan Tano Ponggol & Pangururan & Natural \\
\hline 29. & Kawasan Pohon Boru Naitang & Pangururan & History \\
\hline 30. & Kawasan Pohon Boru Sinaetang & Pangururan & History \\
\hline 31. & Komunitas Tenun Ulos Batak Huta Raja & Pangururan & History and Culture \\
\hline 32. & Monumen Perjuangan Liberty Malau & Pangururan & Culture \\
\hline 33. & Sopo Paromasan Desa Lumban Pinggol & Pangururan & History \\
\hline 34. & Pantai Indah Situngkir & Pangururan & Natural \\
\hline 35. & Menara Doa Sinatapan & Pangururan & Spiritual \\
\hline 36. & Menara Pandang Tele & Harian & Natural \\
\hline 37. & Air Terjun Sampuran Efrata Sosor Dolok & Harian & Natural \\
\hline 38. & Mata Air dan Pohon Pokki & Harian & Natural \\
\hline 39. & Gua Parmonangan & Harian & Natural \\
\hline 40. & Kampung Harimau Situmeang & Harian & Natural \\
\hline 41. & Ulu Darat & Harian & Natural \\
\hline 42. & Hutan Flora Anggrek & Harian & Natural \\
\hline 43. & Bukit Holbung Si Pege & Harian & Natural \\
\hline 44. & Bukit Sitalmak Talmak & Harian & Natural \\
\hline 45. & Pemandian Aek Sipitu Dai & Sianjur Mula-Mula & History and Culture \\
\hline 46. & Batu Hobon & Sianjur Mula-Mula & History \\
\hline 47. & Komplek Guru Tatea Bulan & Sianjur Mula-Mula & History \\
\hline 48. & Kawasan Sejarah Huta Si Raja Batak & Sianjur Mula-Mula & History and Culture \\
\hline 49. & Perkampungan Si Raja Batak Sigulatti & Sianjur Mula-Mula & History \\
\hline 50. & Kawasan Wisata Pusuk Buhit & Sianjur Mula-Mula & History and Culture \\
\hline 51. & Aek Si Boru Pareme & Sianjur Mula-Mula & Natural \\
\hline 52. & Batu Holbung & Sianjur Mula-Mula & Natural \\
\hline 53. & Pulau Tulas & Sianjur Mula-Mula & Natural \\
\hline 54. & Air Terjun Hadabuan Nasogop & Sianjur Mula-Mula & Natural \\
\hline 55. & Aek Boras & Sianjur Mula-Mula & Culture \\
\hline 56. & Batu Pargasipan & Sianjur Mula-Mula & Culture \\
\hline 57. & Batu Parhusipan & Sianjur Mula-Mula & Culture \\
\hline 58. & Batu Nanggar & Sianjur Mula-Mula & Culture \\
\hline
\end{tabular}




\begin{tabular}{|c|c|c|c|}
\hline 59. & Batu Sawan & Sianjur Mula-Mula & Culture \\
\hline 60. & Ruma Hela & Sianjur Mula-Mula & Culture \\
\hline 61. & Kawasan Wisata Tirta Pea Parogan & Ronggur Nihuta & Natural \\
\hline 62. & Kawasan Wisata Tirta Danau Sidihoni & Ronggur Nihuta & Natural \\
\hline 63. & Aek Liang & Ronggur Nihuta & Natural \\
\hline 64. & Gua Sidam-dam & Ronggur Nihuta & Natural \\
\hline 65. & Batu Simaliting & Ronggur Nihuta & Natural \\
\hline 66. & Batu Hitam & Ronggur Nihuta & Natural \\
\hline 67. & Aek Sipale Onggang & Ronggur Nihuta & Natural \\
\hline 68. & Pantai Pasir Putih di Sukkean & Onan Runggu & Natural \\
\hline 69. & Mual Si Raja Sonang di Pakpahan & Onan Runggu & Natural \\
\hline 70. & Kawasan Wisata Remaja Lagundi & Onan Runggu & History \\
\hline 71. & Pohon Besar Sukkean & Onan Runggu & Natural \\
\hline 72. & Tambun Surlau & Onan Runggu & Natural \\
\hline 73. & Rumah Persaktian Datu Parulas Parultop & Onan Runggu & Culture \\
\hline 74. & Kawasan Wisata Gua Bunda Maria & Palipi & Culture \\
\hline 75 . & Batu Rantai & Palipi & Spiritual \\
\hline 76. & Permandian Air Panas Simbolon & Palipi & Natural \\
\hline 77. & Martua Limang Desa Suhut Nihuta & Palipi & History \\
\hline 78. & Air Terjun Sampuran Pangaribuan & Palipi & Natural \\
\hline 79. & Tugu Toga Sinaga & Palipi & History and Culture \\
\hline 80 . & Mual Boru Saroding di Desa Sabulan & Sitio-tio & History \\
\hline 81. & Mual Datu Parngongo & Sitio-tio & History \\
\hline 82. & Patung Raja Si Lontung & Sitio-tio & History and Culture \\
\hline 83. & Pantai Pasir Putih Sipinggan & Nainggolan & Natural \\
\hline 84. & Batu Guru & Nainggolan & Natural \\
\hline 85. & Polhang & Nainggolan & Natural \\
\hline 86. & Boru Simenak-Menak & Nainggolan & History \\
\hline 87. & Sidabasa & Nainggolan & History \\
\hline
\end{tabular}

The number of tourists visiting Samosir Regency has increased every year. This can be seethrough the following Table 2 :

Table 2. Number of tourists visit to Samosir regency

\begin{tabular}{cccc}
\hline \multirow{2}{*}{ Year } & \multicolumn{2}{c}{ Tourists } & \multirow{2}{*}{ Total (Person) } \\
\cline { 2 - 3 } & Foreign (Person) & Domestic (Person) & \\
\hline 2010 & 20.849 & 97.366 & 118.215 \\
2011 & 22.732 & 109.897 & 132.629 \\
2012 & 25.297 & 119.530 & 144.827 \\
2013 & 25.662 & 124.117 & 149.779 \\
2014 & 30.450 & 140.637 & 171.087 \\
2015 & 34.248 & 141.215 & 175.463 \\
2016 & 35.823 & 154.905 & 190.728 \\
2017 & 55.771 & 222.288 & 278.059 \\
2018 & 65.724 & 312.925 & 378.649 \\
2019 & 50.970 & 367.301 & 418.271 \\
\hline
\end{tabular}

Source: Samosir Regency Tourism Office

The number of hotel and other accommodation businesses available is in Samosir Regency 101 hotel and other accommodation, with as many starred classfication hotel details 4-unit, 19 unit non starred/jasmine classification hotel, and 78-unit other accommodation.

The number of companies and public transport fleets available in Samosir Regency consists of: Public Transportation Bus Owning the Route Permit Inter Regency/City Inter Province with 1 company, with a fleet of 5 units; Public Transportation Bus Owning the Route Permit Inter Regency/City in 
Province with 4 companies, with a fleet of 82 units; Public Transportation Bus Owning the Route Permit Inter Village in Regency with 6 companies, with a fleet of 167 units.

The number of lake transportation facilities in Samosir Regency in 2019 consists of: Speed boat with 48 units, Jet Ski with 29 units, Motorized Ship with 190 units, Ferry Ship with 5 units, dan Tourism Ship with 1 units. The number of pier of lake in Samosir Regency managed by the government is 42 pier of lake, and 2 pier of lake managed by a private.

Health facilities available in Samosir Regency consist of: Hospital as many as 2 units, polyclinic with 6 units, Public Health Center with 12 units, and Subsidiary of Public Health Center with 32 units.

The facilities of worship available in Samosir Regency consist of: Mosque with 7 units, Protestant Church with 337 units, and Chatolic Church with 140 units. Number of restaurants available in Samosir Regency with 462 units. Number of traditional markets available in Samosir Regency with 24 traditional markets.

The existing banking facilities in Samosir Regency are available in every district. Facilities for currency exchange (money changers) are available around the tourist area of Tuktuk, Simanindo Subdistrict.

Tourism is one of the important sectors that can contribute to increasing Local Revenue, so it has an effect on increasing revenue for the region. Regional Original Revenues obtained from the Tourism Sector in 2019 amounted to Rp. 553,788,951, with the following details:

Table-3. Local Government Genuine Revenues from the Tourism Sector in Samosir Regency in 2019

\begin{tabular}{lr}
\hline \multicolumn{1}{c}{ Local government genuine revenues } & Total (Rupiah) \\
\hline Tourism Object Retribution & 141.383 .600 \\
Entertainment Tax & 32.107 .350 \\
Restaurant tax & 152.875 .334 \\
Hotel Tax & 227.422 .667 \\
\hline \multicolumn{2}{c}{ Total } \\
\hline
\end{tabular}

\section{Discussion}

Based on descriptive data obtained by the method of observation, interviews and documentation search results, the authors determine the object's performance score by means of judgement (judgement value).

The rating scale for positive factors, i.e. Strengths and Opportunities are:

$1=$ Very Weak

$2=$ Weak

$3=$ Strong

$4=$ Very Strong

Rating scale for negative factors, namely Weaknesses and Threats are:

$1=$ Very Stong

$2=$ Strong

$3=$ Weak

$4=$ Very Weak 
Weight values are determined based on how important these factors are influential, according to the results of a review of tourism theories. The total value of the maximum weight is 1 (one). To facilitate the assignment of values and weights the Internal Factor Analysis Strategy (IFAS) and External Factor Analysis Strategy (EFAS) tables are:

The results of a study of the Internal Factor Analysis Strategy (IFAS) of Samosir Regency tourism objects can be seen in Table-4, below:

Table-4. Internal Factor Analysis Strategy (IFAS)

\begin{tabular}{|c|c|c|c|c|}
\hline No. & Strength $(\mathrm{S})$ : & Score & Weight & Total \\
\hline 1. & The beauty of nature in each tourism object. & 0,2 & 4 & 0,8 \\
\hline 2. & $\begin{array}{l}\text { Beautiful atmosphere, and clean and cool air conditions to create } \\
\text { comfort. }\end{array}$ & 0,2 & 4 & 0,8 \\
\hline 3. & Samosir as Unesco Global Geoparks. & 0,2 & 4 & 0,8 \\
\hline 4. & Affordability with airports, and other facilities. & 0,15 & 4 & 0,6 \\
\hline 5. & $\begin{array}{l}\text { Availability of transportation facilities to get to the location of tourism } \\
\text { object. }\end{array}$ & 0,2 & 4 & 0,8 \\
\hline 6. & $\begin{array}{l}\text { The History of the Batak Civilization is an added value in supporting } \\
\text { education programs based on local wisdom. }\end{array}$ & 0,2 & 4 & 0,8 \\
\hline 7. & $\begin{array}{l}\text { Cultural uniqueness that can be added value in supporting tourism } \\
\text { programs. }\end{array}$ & 0,2 & 4 & 0,8 \\
\hline No. & Total Strength & Score & Weight & $\begin{array}{c}5,4 \\
\text { Total }\end{array}$ \\
\hline 1. & Limited routine art and culture events. & 0,4 & 2 & 0,8 \\
\hline 2. & Limited financial support for tourism object development. & 0,3 & 2 & 0,6 \\
\hline 3. & There are still residents who breed fish in the tourist area around the lake. & 0,3 & 2 & 0,6 \\
\hline 4. & $\begin{array}{l}\text { There are still residents who dispose of household / livestock waste into } \\
\text { the lake area. }\end{array}$ & 0,4 & 2 & 0,8 \\
\hline 5. & Limitations of good infrastructure in the area of tourism object. & 0,3 & 3 & 0,9 \\
\hline \multirow[t]{2}{*}{6.} & $\begin{array}{l}\text { Still not showing a good personality of the local community in serving } \\
\text { tourists. }\end{array}$ & 0,3 & 3 & 0,9 \\
\hline & Total Weakness & & & 4,6 \\
\hline
\end{tabular}

Strength mentioned above, is a supporting factor in the development of tourism in Samosir Regency as a Tourism City. The weaknesses mentioned above, can be resolved by the policy of establishing an efficient and effective management strategy by the Government by involving community participation.

The results of a study of the External Factor Analysis Strategy (EFAS) on the development of tourism in Samosir Regency as a Tourist City can be seen in Table-5, below:

Table-5. External Factor Analysis Strategy (EFAS)

\begin{tabular}{|c|c|c|c|c|}
\hline No. & Opportunities $(\mathrm{O}):$ & Score & Weight & Total \\
\hline 1. & $\begin{array}{l}\text { Development of Tourism Regions as National Strategic Tourism } \\
\text { Regions by the Central Government. }\end{array}$ & 0,2 & 4 & 0,8 \\
\hline 2. & Lake Toba and Samosir as international tourism destinations. & 0,2 & 3 & 0,6 \\
\hline 3. & $\begin{array}{l}\text { The stipulation of tourism in Samosir Regency as a strategic tourism } \\
\text { destination. }\end{array}$ & 0,2 & 4 & 0,8 \\
\hline 4. & $\begin{array}{l}\text { Samosir Regency tourism sector can create jobs; and grow small and } \\
\text { medium businesses. }\end{array}$ & 0,2 & 4 & 0,8 \\
\hline 5. & The need for tourism for each individual is quite high. & 0,2 & 4 & 0,8 \\
\hline 6. & $\begin{array}{l}\text { The concept of tourism marketing in Samosir Regency has been } \\
\text { supported by digitalization-based promotional media. } \\
\text { Total Opportunities }\end{array}$ & 0,2 & 4 & $\begin{array}{l}0,8 \\
4.6\end{array}$ \\
\hline No. & Threats $(\mathrm{T})$ : & Score & Weight & Total \\
\hline
\end{tabular}


1. Environmental damage due to community exploitation.

2. Environmental damage due to production processing activities by the company.

2. The low awareness of the community in maintaining water cleanliness in the Lake Toba region, which in this case results in damage to the environment around the beach attractions in Samosir.

3. The income of the local community still depends on the availability of natural resources, so that it has the potential to utilize natural resources

0,5

0,5

0,5

0,5 2 around attractions in Samosir.

Total Threats $\operatorname{Total}(O-T)$

0,6

So, the internal factor evaluation value is 0.8 ; while the value of the evaluation of external factors is 0.6 .

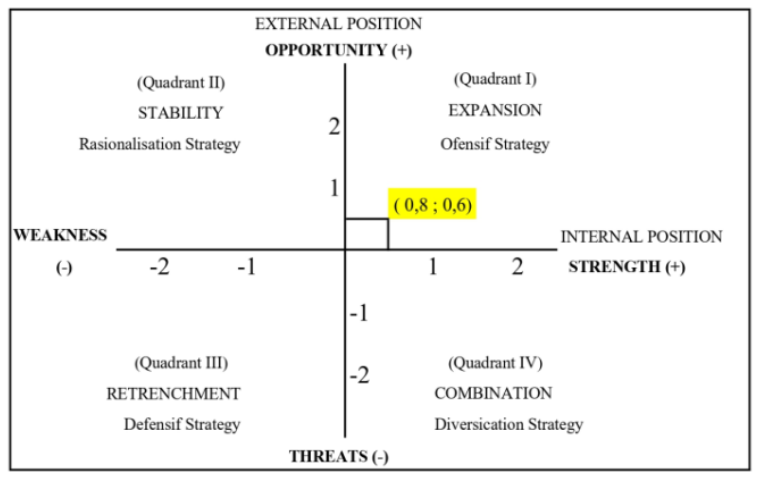

Based on the graph above, it can be explained that based on the weight and rating of each element in the SWOT Matrix, it is known that the position of the tourism object of Samosir Regency is in Quadrant I, namely the Offensive Strategy Quadrant (Expansion) which is located at the coordinates $(0.8 ; 0.6)$. This position explains that the tourism object of Samosir Regency as a tourist attraction in 'Strong Internal and External Conditions', where with this condition the tourism object of Samosir Regency has a good opportunity to be developed into a natural tourism area, cultural tourism, spiritual tourism, and educational tourism, which is supported by various elements of strengths and opportunities, and strives to minimize weaknesses and threats.

Based on the results of a SWOT analysis study of Samosir Regency tourism mentioned above, the writer tries to outline some of the strategies that need to be set for the development of tourism in Samosir Regency through SWOT Analysis, that is:

1. SO (Strength and Opportunities) strategy, which is a strategy that optimizes Strength to take advantage of Opportunities. The forms of SO strategies are:

a) Improving Regional Tourism Core Competencies, namely the superiority of resources possessed, including natural resources and the ability of a region in the tourism sector to build competitiveness in the context of developing the regional economy. The targets of the development of the tourism sector in Samosir Regency as a Tourism City include utilizing resources including natural resources owned by the region optimally, increasing regional competitiveness based on regional superiority owned, increasing the added value in the tourism commodity chains and building the uniqueness of the region. Steps that can be taken for the development of attractions are through the development of attractions that are divided into several clusters, namely Leading Tourism Destinations, Priority Tourist Destinations, and Pioneer Travel Destinations. Obalade and Dubey (2014) state that there are several main determinants that can make a country a potential place to attract foreign direct investment in the tourism sector, that is infrastructure, such as domestic and international airports; highway; 
bridge; international standard lodging facilities; strategic tourist location; natural resources; historical attractions; social security, such as threats from terrorism and natural disasters; national policies and laws; and others. Ardahaey (2011) states that the future tourism product trends that have been predicted by the World Tourism Organization, namely Adventure travel, such as to the world's highest peaks, to underwater sites and places on the "ends of the earth"; Cruise ship; Culture tourism; Ecotourism is a trip that contains natural components; and Thematic tourism. Based on the Regional Government Financial Report, the Samosir Regency Government allocated a 2019 budget for the Tourism Sector of IDR 15,671,669,839.00 with the following details: Office Administration Services Program, with a budget of IDR 1,510,574,839.00; Apparatus Facilities and Infrastructure Improvement Program, with a budget of IDR 108,500,000.00; Tourism Actor Skills and Competence Improvement Program, with a budget of IDR 481,634,000.00; Culture-based Tourism Vocational Strengthening Program, with a budget of IDR 206,104,000.00; Increasing the Competitiveness of Industry to Tourism, with a budget of IDR 125,000,000.00; Tourism Facilities and Infrastructure Arrangement Program, with a budget of IDR 100,300,000.00; Tourism marketing development program, with a budget of IDR 2,533,613,613.00; Tourism destination development program, with a budget of IDR 10,605,943,387.00.

b) Preparing facilities and infrastructure that are well standardized, to create the value of comfort and safety, so as to support the formation of overall quality of tourism products. The available facilities and infrastructure are expected to be able to improve the quality standard of eligibility.

c) Providing tourism facilities and accommodation that is well standardized, to create a value of comfort, cleanliness and good security. The facilities and accommodations referred to above are hotels, villas, retail centers, banking facilities, and hospitals that have the best facilities. This effort is a form of tourism concept in Samosir Regency as an integrated economic and tourism area.

d) Adding routes and fleet of Ferry Ships and Tourist Ships as crossing transportation owned or managed by the Government of Samosir Regency. The increasing number of Ferry Boat routes and fleets is expected to make it easier for tourists to visit Samosir, and eventually will increase the number of domestic and international tourists.

Table-6. Ferry Boat Route

\begin{tabular}{ccccc}
\hline No. & Route & Time & Departure Day & Fleet \\
\hline 1. & Simanindo - Tigaras & $07.00-19.00 \mathrm{Wib}$ & Monday - Sunday & KMP Sumut I \& II \\
2. & Ambarita - Ajibata & $08.30-18.30 \mathrm{Wib}$ & Monday - Sunday & KMP Ihan Batak \\
3. & Tomok - Ajibata & $06.00-19.00 \mathrm{Wib}$ & Monday - Sunday & KMP Tao Toba I \& II \\
4. & Muara - Sipinggan & $06.30-17.00 \mathrm{Wib}$ & Monday - Sunday & KMP Muara Putih \\
\hline
\end{tabular}

e) Increasing annual national and international events or routine events, such as cultural parties, folk parties, music festivals and various sports activities. This activity aims to promote the natural, cultural and cultural potential of Samosir Regency. The form of an annual event that has been included in the national event calendar as a form of tourism promotion in Samosir Regency is Horas Samosir Fiesta, and this event has been included in the National Top 100 Events.

f) Maintaining the values of local wisdom that prevails in people's lives, so that it can be a selling point in supporting various cultural parties and folk events. Cultural tourism is a type of tourism that utilizes the potential of local wisdom possessed by the local community as an object of tourist attraction. Cultural tourism can help in preserving and maintaining cultural heritage as 
the local community's self-identity. Through cultural performances, tourists will get to know the social life of the local community.

2. WO (Weakness and Opportunities) strategy, which is a strategy that minimizes weakness by utilizing opportunities (Opportunities). The forms of the WO strategy are:

a) Building good facilities and infrastructure to attract tourists. This is in consistent with research by Vladi (2014), which states that in order to increase the number of tourists, resources on tourism objects must be considered, and a warm welcome from the local community, so that they can provide a good and unforgettable experience for tourists.

b) Managing tourism objects that are integrated and well-coordinated, so as to guarantee the quality of tourism products and services.

c) Promoting or marketing tourism continuously for tourism objects in Samosir Regency, both domestically and abroad. The purpose of this promotion is: First, to introduce various potentials possessed by Samosir Regency. Second, look for opportunities for potential new customers abroad. Third, maintaining the loyalty of consumers (tourists) who have visited tourism objects in Samosir Regency.

d) Management of the environment around the tourist attraction effectively and sustainably, so that the environment of the tourist area so as to create the value of cleanliness, coolness and beauty.

e) The local government must collaborate with investors both domestic and foreign to support the development of tourism objects in Samosir Regency in a sustainable manner. This is in accordance with Vladi's (2014) research which states that the strategy for sustainable tourism development is to involve all stakeholders and plan concrete steps to achieve a good position as a tourism destination. Richardson (2014) states that one of the factors that can contribute to supporting the success of sustainable tourism development is cooperation between various partners in achieving goals in the tourism sector.

f) The local government is deemed necessary to hold a meeting in the form of a "Community Tourism Business Forum" to the tourism management agency originating from within the country and abroad.

g) Empowering, counseling and training elements of the community, in order to foster and increase awareness and important role of the community in the tourism sector. Richardson (2014) states that one of the factors that can contribute to supporting the success of sustainable tourism development is the involvement of local communities in planning, development and management of the tourism sector. One form of local community empowerment is to support the community to establish micro and small businesses. The activity of promoting the establishment of micro and small businesses owned by local communities involved in the tourism sector is an effort to support poverty alleviation.

3. ST (Strength and Threats) strategy, which is a strategy that uses Strength to overcome Threats. The forms of the ST strategy are:

a) Making Samosir Regency tourism as a geological-based educational tourism area (Geowisata). Samosir area is directed to be a research laboratory for various types of plants, animals, rocks, moisture content, chemical elements, etc.

b) Making Samosir Regency tourism as an educational environment based on the Smart Environment, which is an environmental education program that refers to the concept of a green economy.

c) The local government must make Samosir Regency tourism as an educational area based on local wisdom, namely education that utilizes regional values in terms of economic, cultural, linguistic, information and communication technology, and ecology. 
d) Maintaining the preservation of the natural environment through reforestation (greening) programs.

e) Conducting better and professional management of attractions, so as to create an impression and a good traveling experience from tourists.

4. WT (Weakness and Threats) strategy, which is a strategy that minimizes Weakness and avoids Threats. The forms of the WT strategy are:

a) Improving the quality of human resources, both for the community and tourism actors, so as to create skilled and competent personnel to support the improvement of the quality of tourism sector services.

b) Making management of tourist destinations that are more professional and quality, so that it can increase the number of tourists in a sustainable manner.

c) Developing (differentiation) the value of tourist attraction products. Apart from being a nature tourism, cultural tourism, historical tourism, spiritual tourism and educational tourism, Samosir Regency can develop other types of tourism, such as water tourism and agro tourism. The existence of Samosir, which is right in the middle of Lake Toba, provides a good opportunity to develop water tourism. Potential of natural resources Samosir Regency which is in the mountains, will provide benefits to develop agriculture-based tourism (agro tourism).

d) Manage various supporting facilities that already exist in the tourist attraction effectively and sustainably.

e) Maintaining the survival of natural resources available in the area of attractions.

f) Perfecting legal instruments for the regulation of the life of the tourism industry which is conducive, and worth the benefits. One legal instrument that needs to be determined is the legal provisions concerning the ease of investing in supporting the development of the tourism sector, and the legal provisions regarding support in maintaining sustainable natural resources.

\section{Conclusions}

Based on the results of the discussion of this study, it is concluded that for tourism development strategies in Samosir Regency, they are (1) improving the quality of facilities and infrastructure that supports tourism, such as access to roads, transportation, and adequate accommodation facilities, (2) increasing tourism activities on a national and international scale, (3) doing the promotion of attractions on an ongoing basis to the national and international level, (4) developing various values of tourist attraction products (5) involving the participation of the community and all interested parties in the management of attractions and (6) improving the competency of human resources in the tourism actors.

Samosir Regency has the potential of abundant natural resources that can be utilized and managed to support the tourism sector. The participation of all parties (both the community, government, academics and tourism industry players) is needed in realizing Samosir Regency as a tourist attraction, based on nature tourism, cultural tourism, spiritual tourism and as a center for educational development. The role of the local government is very large in managing and developing all tourism objects to be better, professional and quality. Besides that, an increase in the quality of human resources was carried out from all parties supporting the tourism sector, so as to be able to have competitiveness to support the progress of the tourism sector in Samosir Regency.

The limitation of this study is that it only discusses the potential resources possessed by Samosir Regency, so that internal factors (as strengths and weaknesses) and external factors (as opportunities and threats) can be identified in supporting tourism development. Future research is expected to discuss how the impact of tourism activities in Samosir Regency in increasing regional economic growth, increasing community income, and reducing poverty levels. 


\section{References}

Afrizal. (2016). Metode Penelitian Kualitatif. RajaGrafindo Persada Publisher. Jakarta.

Ardahaey, Fateme Tohidy. (2011). Economic Impacts of Tourism Industry. International Journal of Business and Management, Vol. 6, No. 8, pp. 206-215. doi:10.5539/ijbm.v6n8p206.

Aref, Fariborz. (2011). The Effects of Tourism on Quality of Life: A Case Study of Shiraz Iran. Life Science Journal, Volume 8, Issue 2, pp. 26-30.

Samosir Regency Central Statistics Agency. (2020). Samosir Regency in Figures 2020.

Feili, Hamidreza, et al. (2017). SWOT Analysis for Sustainable Tourism Development Strategies Using Fuzzy Logic. 3rd International Coference of Science and Engineering In the Technology Era, pp. $1-10$.

Goranczewski, Boleslaw., and Puciato, Daniel. (2010). SWOT Analysis In the Formulation of Tourism Development Strategies for Destinations. Tourism, 20, 2, pp. 45-53.

Gnanapala, W.K Athula., and Sandaruwani, J.A.R.C. 2016. Impacts of Tourism Development in Cultural and Heritage Sites: An Empirical Investigation. International Journal of Economics and Business Administration, Vol. 2, No. 6, pp. 68-78.

Hitt, A. Michael, et al. (1997). Manajemen Strategis: Menyongsong Era Persaingan dan Globalisasi. Penerbit Erlangga. Jakarta.

Hunger, J. David dan Thomas L. Wheelen. (2003). Manajemen Strategis. Penerbit Andi. Yogyakarta.

Manzoor, Faiza, et al. (2019). The Contribution of Sustainable to Economic Growth and Employment in Pakistan. International Journal of Environmental Research and Public Health, 16 (19): 3785. doi: 10.3390/ijerph16193785.

Meyer, Natanya., and Meyer, Danie. (2015). The Role and Impact of Tourism on Local Economic Development: A Comparative Study. African Journal for Physical, Helath Education, Recreation and Dance (AJPHERD), Volume 21 (1:1), pp. 197-214.

Obalade, Timothy A. Falade., and Dubey, Suchi. (2014). Managing Tourism as a Source of Revenue and Foreign Direct Investment Inflow in a Developing Country: The Jordanian Experience. International Journal of Academic Research in Economics and Management Sciences, Vol. 3, No. 3, pp. 16-42. DOI: 10.6007/IJAREMS/v3-i3/901.

Regional Government Financial Report in 2019. (2020). Samosir Regency.

Richardson, Robert B. (2014). The Contribution of Tourism to Economic Growth and Food Security. Accelerated Economic Growth Team. USAID from the American People-MALI.

Satya, Mutia Tri, et al. (2018). SWOT Analysis of Marketing Tourism in Leading Tourism Object of Bandung and Soppeng. International Journal of Organizational Innovation, Volume 11, Number 2, pp. 300-314.

Sugiyono. (2010). Metode Penelitian Kuantitatif, Kualitatif, dan R\&D. Penerbit Alfabeta. Bandung.

Undang-Undang Republik Indonesia Nomor 10 Tahun 2009 Tentang Kepariwisataan.

Undang-Undang Republik Indonesia Nomor 28 Tahun 2009 Tentang Pajak Daerah dan Retribusi Daerah.

Vladi, Eriketa. (2014). Tourism Development Strategies, SWOT Analysis and Improvement of Albania Images. European Journal of Sustainable Development, 3, 1, pp. 167-178. 
Zaei, Mansour Esmaeil., and Zaei, Mahin Esmaeil. (2013). The Impacts of Tourism Industry on Host Community. European Journal of Tourism Hospitally and Research, Vol. 1, No. 2, pp. 12-21.

Analisis SWOT Untuk Strategi Pengembangan Pariwisata Kabupaten Samosir

\begin{abstract}
Abstrak
Kabupaten Samosir merupakan kawasan yang berpotensi untuk dikembangkan sebagai destinasi pariwisata melalui pemanfaatan berbagai potensi keindahan alam, kearifan lokal, dan nilai sejarah peradaban budaya, sehingga dapat meningkatkan pendapatan daerah, meningkatkan perekonomian masyarakat, menumbuhkan dunia usaha, memperkenalkan nilai-nilai budaya lokal, dan berkontribusi dalam mengembangkan dunia pendidikan. Penelitian ini bertujuan untuk menganalisis kekuatan, kelemahan, peluang dan ancaman dalam pengembangan pariwisata di Kabupaten Samosir sebagai objek wisata. Pengumpulan data dilakukan melalui observasi, wawancara dan studi pustaka. Analisis data menggunakan analisis deskriptif kualitatif. Hasil data tersebut akan digunakan untuk mengetahui kekuatan, kelemahan, peluang dan ancaman obyek wisata di Kabupaten Samosir. Kesimpulan dari penelitian ini menyatakan bahwa untuk strategi pengembangan pariwisata Kabupaten Samosir adalah: Pertama, Meningkatkan kualitas sarana dan prasarana yang mendukung pariwisata. Kedua, Meningkatkan aktivitas pariwisata dalam skala nasional dan internasional. Ketiga, lakukan promosi objek wisata secara berkesinambungan ke tingkat nasional dan internasional. Keempat, mengembangkan berbagai nilai produk daya tarik wisata. Kelima, libatkan partisipasi masyarakat dan semua pihak yang berkepentingan dalam pengelolaan atraksi. Keenam, Meningkatkan kompetensi sumber daya manusia pelaku pariwisata.
\end{abstract}

Kata kunci: Analisis SWOT, pengembangan pariwisata, kabupaten samosir

\title{
Biographies of authors
}

Toman Sony Tambunan, born in Medan, worked as a State Civil Servant (ASN), where previously worked in the North Tapanuli Regency Government from 2006 to 2013, and from 2014 until now has worked as a civil servant in the Medan City Government, North Sumatra Province. Several strategic structural positions in the government bureaucracy have been occupied.

As an academic, the author is a permanent lecturer for the Management Department at one of the leading private universities in Medan, and is also active as a guest lecturer at several other private universities in Medan.

As a practitioner, the author has worked in a private company engaged in a Palm Oil Mill from 2004 to 2006 in the Process Department in the Clarification section. In addition, the author was given the trust to become one of the supervisory bodies in a cooperative institution, and to become a member of the Audit Board team in a religious institution. The author is given the trust to become Associate Editors and Reviewer at several accredited National and International Journals. Actively sharing knowledge as a resource in several socialization events, seminars, training and official meetings. The author has also provided numerous consultations in the field of regional financial and asset management to several government agencies. The author is active as a member and administrator in professional professional organizations, organizations within academia, and several other social organizations.

The author has completed Strata-1 (Faculty of Economics, Department of Management) in 2003 and Strata-2 (majoring in Management Science) in 2010 at the University of North Sumatra, Medan. Currently, the author is completing his study in Management Science Doctoral Program at the University of North Sumatra. 
To increase knowledge in the field of government, the author has attended many in-service trainings, including on regional finance, government accounting, government financial reports, regional asset management, taxation, regional archives, audits, procurement of government goods / services. In the field of Government Audit, the author has obtained Expert Auditor Certification. The author has also obtained Regional Financial Treasurer Certification; Expert Level Staffing Analyst Certification; Regional Financial Accounting Certification; Government Procurement Certification of Goods and Services; as well as several other Expertise Certification programs.

Actively following developments in the fields of management, leadership, economics, education, finance, entrepreneurship, business and motivation, where the author continues to hone his knowledge by attending various seminars and workshops. Several achievements have been made in participating in the Scientific Writing Competition at the National Level. The author's areas of interest are Management, Leadership, Education and Personal Development.

As a researcher, his writing has been published in various accredited National and International Journals. As a writer, where the author has published his writings in book form by national scale publishers, including: "Government Dictionary" in 2015; "Leaders and Leadership" in 2015; "Glossary of Government Terms" in 2016; "Cooperative" in 2017; "Intelligence Based Leadership" in 2018; "Arif in Interpreting" in 2019; "Business Law" in 2019; "Standard Operating Procedures for Government Agencies" in 2019, and "Management of Cooperatives" in 2019. In addition, he has participated as Author Contributors in the book: "Our Opinions for 67 Years of Indonesian Cooperatives" in 2014; "Sky Script: An Anthology of Poetry" in 2019; "Looking at the Face of Indonesian Education in the 4.0 Era" in 2020.

The books that will soon be published include: "Regional Property Management"; "The Principles of Investment in Indonesia"; "Community development"; "Banks and Other Financial Institutions". 